Proc. Indian Acad. Sci. (Chem. Sci.), Vol. 96, No. 6, April 1986, pp. 459-464.

(C) Printed in India.

\title{
Metal-hydrazine complexes as precursors to oxide materials
}

\author{
K C PATIL \\ Department of Inorganic and Physical Chemistry, Indian Institute of Science, \\ Bangaiore 560012, India
}

\begin{abstract}
Metal-hydrazine complexes, $\left[M\left(\mathrm{~N}_{2} \mathrm{H}_{4}\right)_{n}\right]^{2+}(M=\mathrm{Mn}, \mathrm{Fe}, \mathrm{Co}, \mathrm{Ni}, \mathrm{Zn}$ and $\mathrm{Cd}$, $n=2$ or 3) with different anions like sulphate, sulphite, acetate, formate, oxalate, hydrazinocarboxylate, nitrate and perchiorate have been investigated as precursors to oxide materials. The thermal reactivity of these complexes changes dramatically with the anion, e.g. sulphate, sulphite, acetate and formate complexes-docompose; oxalate and hydrazinocarboxylates-deflagerate and nitrate and perchlorate complexes-detonate. The deflagerating nature of the metal-hydrazine oxalates and hydrazinocarboxylates has been employed in the combustion synthesis of fine particle $\gamma-\mathrm{Fe}_{2} \mathrm{O}_{3}, \mathrm{Fe}_{3} \mathrm{O}_{4}$, ferrites and cobaltites at low temperature.
\end{abstract}

Keywords. Metal-hydrazine complexes; precursors to oxide materials.

\section{Introduction}

The chemistry of hydrazine is of interest since it has a potent $\mathrm{N}-\mathrm{N}$ bond, two free electron pairs and four substitutable $\mathrm{H}$-atoms. The coordination of hydrazine to the metal ion can either be as a unidentate or bridged bidentate ligand. Hydrazine has positive heat of formation $\left(\Delta H_{f}^{\circ}=\sim 12 \mathrm{kcal} \mathrm{mol}^{-1}\right)$ and therefore is thermodynamically unstable. Practically, however, it is quite stable and can be handled safely. Hydrazine is susceptible to catalysis and can explode even at room temperature in presence of rust $\left(\mathrm{Fe}_{2} \mathrm{O}_{3}\right)$. Thermal reactivity of metal-hydrazine complexes is of interest since the stability of the complexes changes dramatically, depending upon the anion as well as the cation. In this paper, an attempt is made to correlate the reactivity of metalhydrazine complexes, $\left[M\left(\mathrm{~N}_{2} \mathrm{H}_{4}\right)_{n}\right]^{2+}(M=\mathrm{Mn}, \mathrm{Fe}, \mathrm{Co}, \mathrm{Ni}, \mathrm{Zn}$ and $\mathrm{Cd}, n=2$ or 3$)$ as a function of anions like sulphate, sulphite, acetate, formate, oxalate, hydrazinocarboxylate, nitrate and perchlorate.

\section{Experimental}

\subsection{Preparation of metal-hydrazine complexes, $M\left(\mathrm{~N}_{2} \mathrm{H}_{4}\right)_{n} X_{2}$}

The general method of the preparation of metal hydrazine complexes, $M\left(\mathrm{~N}_{2} \mathrm{H}_{4}\right)_{n} X_{2}$ ( $M=\mathrm{Mn}, \mathrm{Fe}^{*}, \mathrm{Co}, \mathrm{Ni}, \mathrm{Zn}$ and $\mathrm{Cd}, n=2$ or 3 ), and $X=$ acetate, oxalate, formate nitrate or sulphate) involves the reaction of an aqueous solution of the corresponding metal salt with alcoholic hydrazine hydrate.

$$
M X_{2}\left(\text { aq) }+n \mathrm{~N}_{2} \mathrm{H}_{4} \cdot \mathrm{H}_{2} \mathrm{O} \text { (alcoholic) } \rightarrow M\left(\mathrm{~N}_{2} \mathrm{H}_{4}\right)_{n} X_{2}+n \mathrm{H}_{2} \mathrm{O}\right. \text {. }
$$

\footnotetext{
* Fe complexes are unstable and spontaneously ignite during suction drying.
} 
The complexes can also be prepared by dissolving the metal powders in a solution of ammonium $\left(\mathrm{NH}_{4}^{+}\right)$or hydrazinium $\left(\mathrm{N}_{2} \mathrm{H}_{5}^{+}\right)$salts in hydrazine hydrate or water,

$$
\begin{aligned}
& M^{0}+2 \mathrm{NH}_{4} X+2 \mathrm{~N}_{2} \mathrm{H}_{4} \cdot \mathrm{H}_{2} \mathrm{O} \rightarrow M\left(\mathrm{~N}_{2} \mathrm{H}_{4}\right)_{2} X_{2}+2 \mathrm{NH}_{3}+2 \mathrm{H}_{2} \mathrm{O}+\mathrm{H}_{2}, \\
& M^{0}+2 \mathrm{~N}_{2} \mathrm{H}_{5} X+\mathrm{H}_{2} \mathrm{O} \rightarrow M\left(\mathrm{~N}_{2} \mathrm{H}_{4}\right)_{2} X_{2}+\mathrm{H}_{2}+\mathrm{H}_{2} \mathrm{O} .
\end{aligned}
$$

Metal sulphite and metal hydrazinocarboxylate hydrazine complexes were prepared by the reaction of aqueous metal ions with hydrazine hydrate saturated with $\mathrm{SO}_{2}$ and $\mathrm{CO}_{2}$, respectively,

$$
\begin{aligned}
& M^{2+}+x \mathrm{~N}_{2} \mathrm{H}_{4} \cdot \mathrm{H}_{2} \mathrm{O}+\mathrm{SO}_{2} \rightarrow M \mathrm{SO}_{3} \cdot x \mathrm{~N}_{2} \mathrm{H}_{4} \cdot y \mathrm{H}_{2} \mathrm{O}+(x-y) \mathrm{H}_{2} \mathrm{O}, \\
& M X_{2}+4 \mathrm{~N}_{2} \mathrm{H}_{4} \cdot \mathrm{H}_{2} \mathrm{O}+2 \mathrm{CO}_{2} \rightarrow M\left(\mathrm{~N}_{2} \mathrm{H}_{3} \mathrm{COO}\right)_{2}\left(\mathrm{~N}_{2} \mathrm{H}_{4}\right)_{2}+4 \mathrm{H}_{2} \mathrm{O}+2 \mathrm{HX},
\end{aligned}
$$

\subsection{Analysis}

The metal content in the complexes was determined by EDTA complexometric titrations. Hydrazine content was estimated volumetrically using $0.025 \mathrm{M} \mathrm{KIO}_{3}$ solution under Andrews conditions (Vogel 1961).

\subsection{Physiocochemical studies}

Infrared spectra of the complexes were recorded as nujol mulls or $\mathrm{KBr}$ discs using a Perkin-Elmer 781 spectrophotometer. Simultaneous TG-DTG-DTA of the complexes were recorded using a TGD-5000 RH thermobalance of ULVAC Sinku Riko, Japan. Thermal analysis curves were recorded in air using $4-5 \mathrm{mg}$ samples. The heating rate employed was $10^{\circ} \mathrm{C} / \mathrm{min}$. Platinum cups were used as sample holders.

The decomposition/combustion residues of the complexes were characterized by $x$-ray powder diffraction patterns recorded on a Philips PW 1050/70 diffractometer using $\mathrm{Cu} \mathbf{K}_{\alpha}$ and $\mathrm{Co} \mathbf{K}_{\alpha}$ radiation.

Temperature profile measurements to determine the surface temperatures in the combustion of $\mathrm{FeC}_{2} \mathrm{O}_{4} \cdot 2 \mathrm{~N}_{2} \mathrm{H}_{4}$ and $\mathrm{Fe}\left(\mathrm{N}_{2} \mathrm{H}_{3} \mathrm{COO}\right)_{2}\left(\mathrm{~N}_{2} \mathrm{H}_{4}\right)_{2}$ were carried out using chromel-alumel thermocouple embedded in $1 \mathrm{~cm}^{3}$ pellets. A time-temperature plot was obtained by feeding the output to a strip-chart recorder.

BET surface area of $\mathrm{Fe}_{3} \mathrm{O}_{4}, \gamma-\mathrm{Fe}_{2} \mathrm{O}_{3}$, ferrites and cobaltites were measured by nitrogen adsorption using Micromeritics Accusorb $2100 \mathrm{E}$ instrument. Mossbauer spectra of $\mathrm{Fe}_{3} \mathrm{O}_{4}$ and $\gamma-\mathrm{Fe}_{2} \mathrm{O}_{3}$ were recorded at room temperature employing a ECIL MBS 35 spectrophotometer with a multichannel analyser. Coercivity of $\gamma-\mathrm{Fe}_{2} \mathrm{O}_{3}$ was measured using EG \& G vibrating sample magnetometer fitted with bipolar power supply.

\section{Results and discussion}

Preparation, infrared spectra and thermal analysis of metal-hydrazine complexes $\left[M\left(\mathrm{~N}_{2} \mathrm{H}_{4}\right)\right]^{2+}(M=\mathrm{Mn}, \mathrm{Fe}, \mathrm{Co}, \mathrm{Ni}, \mathrm{Zn}$ and $\mathrm{Cd})$ with anions like nitrate, perchlorate and azide (Patil et al 1982b), oxalate (Patil et al 1982a), formate (Ravindranathan and Patil 1983), hydrazinocarboxylate (Ravindranathan and Patil 1985), sulphate (Patil et 
al 1981; Govindarajan et al 1985), acetate (Mahesh and Patil 1985) and sulphite (Budkuley 1984) have been investigated.

The hydrazine molecule is coordinated to the metal as a bridged bidentate ligand in all these complexes except in the case of hydrazinocarboxylates in which it is coordinated to the metal atom as a unidentate ligand. Infrared spectra serve as a finger print technique and the presence of unidentate $\mathrm{N}_{2} \mathrm{H}_{4}$ in $M\left(\mathrm{~N}_{2} \mathrm{H}_{3} \mathrm{COO}\right)_{2}\left(\mathrm{~N}_{2} \mathrm{H}_{4}\right)_{2}$ is indicated by the characteristic $N-N$ stretching frequency of $\mathrm{N}_{2} \mathrm{H}_{4} \sim 930 \mathrm{~cm}^{-1}$ (Nicholls and Swindells 1968). The $x$-ray crystal structure of $\mathrm{Zn}\left(\mathrm{N}_{2} \mathrm{H}_{3} \mathrm{COO}\right)_{2}\left(\mathrm{~N}_{2} \mathrm{H}_{4}\right)_{2}$ has been determined and the structures of $\mathrm{Mn}, \mathrm{Fe}, \mathrm{Co} \& \mathrm{Ni}$ complexes are reported to be isomorphous (Ferrari et al 1966). This study supports the presence of unidentate $\mathrm{N}_{2} \mathrm{H}_{4}$ in these complexes.

The presence of bridged bidentate hydrazine in sulphate, sulphite, formate, acetate, nitrate and oxalate complexes has been indicated by the presence of $v_{N-N}$ of $\mathrm{N}_{2} \mathrm{H}_{4}$ in the region $960-980 \mathrm{~cm}^{-1}$ (Patil et al 1981, 1982a, b; Braibanti et al 1968) and x-ray crystal structure studies (Ferrari et al 1965).

Thermal reactivity of metal-hydrazine complexes has been investigated by TG-DTA studies. Table 1 summarizes the results of the thermal decomposition of metal sulphate, sulphite, formate and acetate hydrazine complexes. All these complexes initially lose hydrazine exothermically leaving behind the respective metal salts which decompose to the corresponding metal oxides at higher temperatures. The oxide formation temperatures are lower compared to those reported for hydrated metal salts. The metal salts formed by the dehydrazination of the complexes are reactive and decompose at lower temperatures.

Table 2 summarizes the results of TG-DTA studies of metal nitrate, oxalate and hydrazinocarboxylate hydrazine complexes. All these complexes show single step decomposition in TG giving corresponding metal oxides. The decomposition of nitrate complexes is violent. The oxalate and hydrazinocarboxylate complexes exhibit autocatalytic combustion behaviour, i.e., combustion is self-sustained once initiated.

Table 1. Thermogravimetric (temperature range ${ }^{\circ} \mathrm{C}$ ) and differential thermal analysis* (peak temperature ${ }^{\circ} \mathrm{C}$ ) data of metal hydrazine complexes $M\left(\mathrm{~N}_{2} \mathrm{H}_{4}\right)_{2} X_{2}$.

\begin{tabular}{|c|c|c|c|c|c|}
\hline Metal (M) & Sulphate & Sulphite & $\begin{array}{l}\text { Anion }(X) \\
\text { Formate }\end{array}$ & Acetate & Reaction \\
\hline Mn & $\begin{array}{c}175-245 \\
(180)\end{array}$ & $\begin{array}{c}202-295 \\
(233)\end{array}$ & $\begin{array}{c}110-178 \\
\text { (170-endo) }\end{array}$ & $\begin{array}{c}130-205 \\
(150,190)\end{array}$ & Dehydrazination \\
\hline $\mathrm{Fe}$ & $\begin{array}{c}100-250 \\
(160)+\end{array}$ & $\begin{array}{c}130-142 \\
(135) \dagger\end{array}$ & - & - & $\begin{array}{l}\text { Dehydrazination and } \\
\text { Decomposition }\end{array}$ \\
\hline Co & $\begin{array}{c}185-385 \\
(200,325)\end{array}$ & $\begin{array}{c}150-160 \\
(157)\end{array}$ & $\begin{array}{c}100-204 \\
(167-\text { endo })\end{array}$ & $\begin{array}{c}160-220 \\
(180,220)\end{array}$ & Dehydrazination \\
\hline $\mathrm{Ni}$ & $\begin{array}{c}230-485 \\
(280,455)\end{array}$ & $\begin{array}{c}104-215 \\
(182)\end{array}$ & $\begin{array}{c}116-233 \\
(217) \dagger\end{array}$ & $\begin{array}{l}190-245 \dagger \\
(205,230)\end{array}$ & Dehydrazination \\
\hline $\mathrm{Zn}$ & $\begin{array}{c}100-425 \\
(110,245,350)\end{array}$ & $\begin{array}{c}200-235 \\
(215)\end{array}$ & $\begin{array}{c}100-324 \\
(168-\text { endo }\end{array}$ & $\begin{array}{c}150-195 \\
(130)\end{array}$ & Dehydrazination \\
\hline $\mathrm{Cd}$ & $\begin{array}{c}155-385 \\
(175,330)\end{array}$ & - & $\begin{array}{c}100-285 \\
\text { (187-endo) }\end{array}$ & $\begin{array}{c}115-215 \\
(175,200)\end{array}$ & Dehydrazination \\
\hline
\end{tabular}

* All DTA peaks are exothermic unless indicated otherwise (endo = endothermic).

$\dagger$ Dehydrazination is accompanied by decomposition. 
Table 2. Thermogravimetric (temperature range ${ }^{\circ} \mathrm{C}$ ) and differential thermal analysis* (peak temperature ${ }^{\circ} \mathrm{C}$ ) data of metal-hydrazine complexes, $M\left(\mathrm{~N}_{2} \mathrm{H}_{4}\right)_{n} X_{2}$.

\begin{tabular}{lllll}
\hline Metal $M$ & Nitrate & \multicolumn{4}{c}{ Oxalate } & $\begin{array}{c}\text { Anion }(X) \\
\text { Hydrazinocarboxylate }\end{array}$ & Product \\
\hline $\mathrm{Mn}$ & $(141)$ & $204-225(217)$ & $130-290(174,195)$ & $\mathrm{MnO}$ \\
$\mathrm{Fe}$ & $(140)$ & $180-310(202)$ & $130-205(135,175)$ & $\mathrm{Fe}_{2} \mathrm{O}_{3}$ \\
$\mathrm{Co}$ & $(188)$ & $204-358(209,262)$ & $210-269(190,200)$ & $\mathrm{Co}_{3} \mathrm{O}_{4}$ \\
$\mathrm{Ni}$ & $(220)$ & $226-419(219,244,290)$ & $187-200(195,228)$ & $\mathrm{NiO}$ \\
$\mathrm{Zn}$ & $(212)$ & $120-466(216,301,406)$ & $155-325(200,310)$ & $\mathrm{ZnO}$ \\
$\mathrm{Cd}$ & $(145)$ & $169-456(182,291,353)$ & - & $\mathrm{CdO}$ \\
\hline
\end{tabular}

*All DTA peaks are exothermic; $† M\left(\mathrm{~N}_{2} \mathrm{H}_{4}\right)_{3}\left(\mathrm{NO}_{3}\right)_{2}$.

The decomposition/combustion of these complexes is accompanied by the evolution of large amounts of gases like $\mathrm{NH}_{3}, \mathrm{H}_{2} \mathrm{O}, \mathrm{CO}_{2}$ and $\mathrm{N}_{2}$. The combustion residues thus left behind are fine and porous metal oxides.

Based on the thermal decomposition studies of metal-hydrazine complexes they can be classified into three distinct groups:

1) Complexes which decompose, i.e., lose hydrazine leaving behind corresponding metal salts. e.g. $M\left(\mathrm{~N}_{2} \mathrm{H}_{4}\right)_{2} X_{2}$, where $X=$ sulphate, sulphite, formate and acetate.

2) Complexes which deflagerate, i.e., exhibit self-sustained (controlled) combustion, e.g. $M\left(\mathrm{~N}_{2} \mathrm{H}_{4}\right)_{2} \mathrm{C}_{2} \mathrm{O}_{4}$ and $M\left(\mathrm{~N}_{2} \mathrm{H}_{3} \mathrm{COO}\right)_{2}\left(\mathrm{~N}_{2} \mathrm{H}_{4}\right)_{2}$.

3) Complexes which detonate, e.g. $M\left(\mathrm{~N}_{2} \mathrm{H}_{4}\right)_{3}\left(\mathrm{NO}_{3}\right)_{2}$ and $M\left(\mathrm{~N}_{2} \mathrm{H}_{4}\right)_{2}\left(\mathrm{ClO}_{4}\right)_{2}$.

This dramatic change in the reactivity of the metal-hydrazine complexes can thus be attributed to the nature of the anion i.e. inert, reducing or oxidising. The sulphate and acetate anions are quite inert and do not exhibit any deflageration or detonation. Whereas formate and sulphite complexes although lose hydrazine during decomposition, exhibit self-sustained combustion like oxalate and hydrazinocarboxylate complexes. The explosive nature of nitrate and perchlorate complexes can be attributed to the redox reactions of oxidizer-fuel groups in the complexes.

The role of cation (metal) is also quite important since the explosive nature of transition metal perchlorate hydrazine complexes (Friedrich and Vervoorst 1926; Maissen and Schwarzenbach 1951) changes to deflageration in the case of magnesium and aluminium perchlorate complexes (Patil et al 1982b). Thus, the highly unstable and explosive nature of $\mathrm{N}_{2} \mathrm{H}_{4}$ can be controlled by suitably complexing it with selective metal ions and anions.

\section{Combustion synthesis}

The deflagerating nature of metal oxalate and hydrazinocarboxylate hydrazine complexes has been employed in the combustion synthesis of fine particle $\mathrm{Fe}_{3} \mathrm{O}_{4}, \gamma$ $\mathrm{Fe}_{2} \mathrm{O}_{3}$, ferrites and cobaltites. 


\subsection{Synthesis of $\mathrm{Fe}_{3} \mathrm{O}_{4}$}

The decomposition/combustion of $\mathrm{Fe}\left(\mathrm{N}_{2} \mathrm{H}_{3} \mathrm{COO}\right)_{2}\left(\mathrm{~N}_{2} \mathrm{H}_{4}\right)_{2}$ in vacuum at $\approx 250^{\circ} \mathrm{C}$ yields finely divided $\mathrm{Fe}_{3} \mathrm{O}_{4}$. Formation of $\mathrm{Fe}_{3} \mathrm{O}_{4}$ was confirmed by $\mathrm{x}$-ray powder diffraction pattern of the residue $(a=8.46 \mathrm{~A})$. The crystallite sizes of $\mathrm{Fe}_{3} \mathrm{O}_{4}$ calculated from $x$-ray line broadening are in the range of 170-250 A. The surface area of $\mathrm{Fe}_{3} \mathrm{O}_{4}$ is $50 \mathrm{~m}^{2} / \mathrm{g}$. The Mossbauer spectrum of $\mathrm{Fe}_{3} \mathrm{O}_{4}$ shows the expected hyperfine spectra with the central doublet indicating super paramagnetic nature of the particles. The DTA of this fine particle $\mathrm{Fe}_{3} \mathrm{O}_{4}$ shows two exotherms at $200^{\circ} \mathrm{C}$ and $630^{\circ} \mathrm{C}$ corresponding to the oxidation of $\mathrm{Fe}_{3} \mathrm{O}_{4} \rightarrow \gamma-\mathrm{Fe}_{2} \mathrm{O}_{3}$ and $\alpha-\mathrm{Fe}_{2} \mathrm{O}_{3}$ respectively.

\subsection{Synthesis of $\gamma-\mathrm{Fe}_{2} \mathrm{O}_{3}$}

The decomposition/combustion of $\mathrm{FeC}_{2} \mathrm{O}_{4}\left(\mathrm{~N}_{2} \mathrm{H}_{4}\right)_{2}$ in air at $\approx 200^{\circ} \mathrm{C}$ yields a mixture of $\gamma$ and $\alpha-\mathrm{Fe}_{2} \mathrm{O}_{3}$ as evidenced by the $\mathrm{x}$-ray powder diffraction of the combustion residue. However, the decomposition/combustion of $\mathrm{Fe}\left(\mathrm{N}_{2} \mathrm{H}_{3} \mathrm{COO}\right)_{2}\left(\mathrm{~N}_{2} \mathrm{H}_{4}\right)_{2}$ in air at $\approx 200^{\circ} \mathrm{C}$ gave $\gamma-\mathrm{Fe}_{2} \mathrm{O}_{3}$ only as indicated by the xRD pattern of the combustion residue $(a=8.37 \mathrm{~A})$. The crystallite sizes of $\gamma-\mathrm{Fe}_{2} \mathrm{O}_{3}$ are in the range of $170-250 \mathrm{~A}$ and the surface area is $40 \mathrm{~m}^{2} / \mathrm{g}$. Mossbauer spectra of $y-\mathrm{Fe}_{2} \mathrm{O}_{3}$ showed the expected hyperfine split pattern. The hyperfine field calculated from the fitting of the spectrum is $490 \mathrm{kOe}$ and the isomer shift is $0.3435 \mathrm{~mm} / \mathrm{sec}$ with respect to stainless steel. The coercivity force observed from the B-H curve of $y-\mathrm{Fe}_{2} \mathrm{O}_{3}$ is 170 oersteds. The DTA of $\gamma-\mathrm{Fe}_{2} \mathrm{O}_{3}$ showed an exotherm at $\approx 630^{\circ} \mathrm{C}$ corresponding to the conversion of $\gamma \rightarrow \alpha \mathrm{Fe}_{2} \mathrm{O}_{3}$.

Temperature profile measurement of $\mathrm{FeC}_{2} \mathrm{O}_{4}\left(\mathrm{~N}_{2} \mathrm{H}_{4}\right)_{2}$ (Kishore et al 1986) showed that the maximum temperature attained during the combustion is $\approx 600^{\circ} \mathrm{C}$ although ignition occurs at $\sim 200^{\circ} \mathrm{C}$. On the other hand, in the case of $\mathrm{Fe}\left(\mathrm{N}_{2} \mathrm{H}_{3} \mathrm{COO}\right)_{2}\left(\mathrm{~N}_{2} \mathrm{H}_{4}\right)_{2}$ combustion the maximum temperature attained was only $425^{\circ} \mathrm{C}$. This difference in the exothermicity of the combustion of $\mathrm{FeC}_{2} \mathrm{O}_{4}\left(\mathrm{~N}_{2} \mathrm{H}_{4}\right)_{2}$ and $\mathrm{Fe}\left(\mathrm{N}_{2} \mathrm{H}_{3} \mathrm{COO}\right)_{2}\left(\mathrm{~N}_{2} \mathrm{H}_{4}\right)_{2}$ is probably responsible for the formation of a mixture of $\gamma, \alpha \mathrm{Fe}_{2} \mathrm{O}_{3}$ in the former and exclusively $\gamma-\mathrm{Fe}_{2} \mathrm{O}_{3}$ in the latter. It is well known that $\gamma-\mathrm{Fe}_{2} \mathrm{O}_{3}$ is converted to $\alpha-\mathrm{Fe}_{2} \mathrm{O}_{3}$ at $\approx 600^{\circ} \mathrm{C}$.

\subsection{Synthesis of ferrites}

The preparation of spinel ferrites by the decomposition/combustion of mixed metal oxalate hydrazinates, $M \mathrm{Fe}_{2}\left(\mathrm{C}_{2} \mathrm{O}_{4}\right)_{3}\left(\mathrm{~N}_{2} \mathrm{H}_{4}\right)_{6}$ where $M=\mathrm{Mn}, \mathrm{Fe}, \mathrm{Co}, \mathrm{Ni}$ and $\mathrm{Zn}$ at low temperatures has been reported (Gajapathy and Patil 1983).

Ultrafine ferrite powders have been prepared by the decomposition/combustion of solid solution precursors of the type $M_{1 / 3} \mathrm{Fe}_{2 / 3}\left(\mathrm{~N}_{2} \mathrm{H}_{3} \mathrm{COO}\right)_{2}\left(\mathrm{~N}_{2} \mathrm{H}_{4}\right)_{2}$, where $M=\mathrm{Mg}, \mathrm{Mn}, \mathrm{Co}, \mathrm{Ni}$ and $\mathrm{Zn}$. These precursors decompose at lower temperatures $\left(125-150^{\circ} \mathrm{C}\right)$ with the evolution of large amounts of gases like $\mathrm{NH}_{3}, \mathrm{H}_{2} \mathrm{O}, \mathrm{CO}_{2}$ and $\mathrm{N}_{2}$ to yield corresponding ferrites. Formation of ferrites was confirmed by their characteristic XRD patterns. The crystallite sizes of the ferrites calculated from the $x$-ray line broadening are in the range of $130-250 \mathrm{~A}$. The surface area of the ferrites range from $75-120 \mathrm{~m}^{2} / \mathrm{g}$.

\subsection{Synthesis of cobaltites}

The preparation of $\mathrm{MgCo}_{2} \mathrm{O}_{4}$ and $\mathrm{NiCo}_{2} \mathrm{O}_{4}$ by the decomposition/combustion of 
$\mathrm{MgCo}_{2}\left(\mathrm{C}_{2} \mathrm{O}_{4}\right)_{3} \cdot 5 \mathrm{~N}_{2} \mathrm{H}_{4}$ and $\mathrm{NiCo}_{2}\left(\mathrm{C}_{2} \mathrm{O}_{4}\right)_{3} \cdot 6 \mathrm{~N}_{2} \mathrm{H}_{4}$ has been reported (Patil et al 1983). The decomposition/combustion of solid solution precursors of the type, $M_{1 / 3} \mathrm{Co}_{2 / 3}\left(\mathrm{~N}_{2} \mathrm{H}_{3} \mathrm{COO}\right)_{2}\left(\mathrm{~N}_{2} \mathrm{H}_{4}\right)_{2}$, where $M=\mathrm{Mg}, \mathrm{Mn}, \mathrm{Fe}, \mathrm{Ni}$ and $\mathrm{Zn}$ yield fine particle cobaltites, $\mathrm{MCo}_{2} \mathrm{O}_{4}$ at low temperatures $\left(200-400^{\circ} \mathrm{C}\right)$. Further work is in progress on the characterization of these cobaltites.

\section{References}

Braibanti A, Dallavalle F, Pellinghelli M A and Leporati E 1968 Inorg. Chem. 71430

Budkuley J S 1984 Ph.D Thesis, University of Bombay

Ferrari A, Braibanti A, Bigliardi G and Lanfredi A M 1965 Acta Cryst. 19548

Ferrari A, Braibanti A, Bigliardi G, Lanfredi A M and Tiripicchio A 1966 Nature (London) 2111175

Friedrich V and Vervoorst P 1926 Z. Gesamte Schiess- Sprengstoffwes. 2149

Gajapathy D and Patil K C 1983 Mater. Chem. Phys. 9423

Govindarajan S, Babu P J and Patil K C 1985 Thermochim. Acta (in press)

Kishore K, Patil K C and Gajapathy D 1986 Explosives, Propellants, Pyrotechnics (in press)

Mahesh G V and Patil K C 1985 Thermochim. Acta (in press)

Maissen B and Schwarzenbach G 1951 Helv. Chim. Acta. 342084

Nicholls D and Swindells R $1968 \mathrm{~J}$. Inorg. Nucl. Chem. 302211

Patil K C, Gajapathy D and Kishore K 1982a Thermochim. Acta 52113

Patil K. C, Gajapathy D and Pai Verneker V R 1983 J. Mater. Sci. Lett. 3272

Patil K C, Govindarajan S, Soundararajan R and Pai Verneker V R 1981 Proc. Indian Acad. Sci. (Chem. Sci.) 90421

Patil K C, Nesamani C and Pai Verneker V R 1982b Synth. React. Inorg. Met.-Org. Chem. 12383

Ravindranathan P and Patil K C 1983 Thermachim. Acta 7153

Ravindranathan P and Patil K C 1985 Proc. Indian Acad. Sci. (Chem. Sci.) 95345

Vogel A I 1961 A text book of quantitative inorganic chemistry 3rd edn. (London: Longmans Green) p. 433 